\title{
O jornalismo e a enunciação: perspectivas para um narrador-jornalista
}

\author{
Fernando Resende
}

\begin{abstract}
Resumo
O olhar voltado ao momento atual implica refletir acerca dos estudos que têm sido desenvolvidos nos campos da comunicação social e, mais especificamente, do jornalismo. O estudo das narrativas, lugar preponderante quando se visa ao reconhecimento das mediações como foco relevante no trabalho de produção de conhecimento do jornalismo e de sua prática, torna-se fundamental, se o que se pretende é rearticular modos de compreender a praxis jornalistica nas sociedades contemporâneas. Este ensaio, recorte de uma pesquisa que busca conhecer a formação e a constituição do discurso jornalístico no Brasil, se debruça sobre a questão da narrativa e a problemática da enunciação. Através de uma reflexão sobre a presença do narrador no principio do romance, busca-se problematizar a narrativa jornalistica, na perspectiva do reconhecimento da existência de um narrador-jornalista, estratégia textual que auxilia no ato de desvelar os fatos e suas verdades.
\end{abstract}

Palavras-Chaves: Jornalismo, romance, narrativa, narrador.

\begin{abstract}
A contemporany look at the studies that have been developed in the fields of Social Communication and fournalism demands thinking upon its process. The study of narratives, a fundamental field once one considers mediations as these fields' relevant focus, turns out to be essential, if one intends to rearticulate ways of comprehending the journalistic praxis in the contemporary societies. This essay, part of a research that intends to understand the constitution and the formation of the journalistic discourse in Brazil, reflects upon the auestion of narrative and the enunciation process. By considering the presence of the narrator in the beginning of the novel, w'e intend to problematize the journalistic narratives, in the perspective of the existence of a narrator-journalist, textual strategy that might help the revealing of the facts and its truths.
\end{abstract}

Key-words: Journalism, novel, narrative, narrator.

\footnotetext{
- Professor e pesquisador do Programa de Pós.Graduação em Comunicação da Pontificia Universidade Católica do Rio de Janeiro (PUC-Rio). Mestre em Estudos Literários (UFMC) e Doutor em Ciências da Comunicaçào (USP).
} 
Na dimensão de um contemporâneo em que as sociabilidades se configuram por vias mediatizadas, a noção de espaço público, como lugar simbólico em que se tecem e se estabelecem as relações sociais, ganha relevos significativos. Trata-se de fatores que, principalmente por alterarem as relações que as pessoas estabelecem com as noções de espaço e de tempo, reconfiguram os papéis e as pertinências dos vários campos que constituem a sociedade. As relações, que de diretas passam a ser sobrepostas, e nunca substituídas, pelas de circulação mediática, se conformam em um espaço cuja ordem se estabelece a partir de uma correlação de forças. No âmbito do espaço público conflituoso', são os vários campos e organizações sociạis coexistentes, através dos quais se articulam os saberes e as práticas cotidianas, que se reorganizam, constantemente. Nesse sentido, o avanço tecnológico sofrido pela sociedade, que tem se configurado nos últimos 50 anos, é um dado preponderante.

O campo dos media, como também o são os outros; tanto se faz autônomo como dependente. Em outras palavras, ele instaura, ao mesmo tempo em que conforma e redefine, discursos sobre e para a sociedade; ou seja, ele cria e recria práticas sociais discursivas que tanto desejam falar da sociedade como se constituir enquanto saber acerca desta mesma sociedade. Junte-se a estes aspectos, ainda, o fato de que o campo dos media narra experiências e modos de vida calcados em subjetividades que estão, insistentemente, cravadas na objetividade demandada pela necessária lida com o cotidiano. Ou seja, eles interferem no status quo e recriam modos de vida, porque lêem e provocam releituras de experiências subjetivas e objetivas e, vale dizer, de forma às vezes tão imperativa que se tornam o lugar de onde as pessoas retiram o que sabem e o que se dispõem a compreender acerca do cotidiano e da vida.

\section{Da narrativa}

Os estudos da mídia, somente nos últimos 10 ou 15 anos, têm buscado recuperar o processo de comunicação em sua dimensão complexa - a que diz respeito à tríade produção / circulação / recepção. E nessa perspectiva, tanto os Estudos Culturais têm servido como fonte relevante quanto, por exemplo, a Psicanálise, os Estudos Literários e a Antropologia têm contribuído para a construção de olhares interdisciplinares, fazendo-se fundamentais para uma compreensão mais abrangente da sociedade da informação e/ou da comunicação. Assim, no tempo presente, quando a sociedade adquire dimensões tão complexas e quando as interrelações se estabelecem de forma tão imediata devido mesmo ao avanço tecnológico suscitado pela própria modernidade, há que se fazer ressaltar que se não nos atentarmos para algumas atrofias que têm marcado os estudos nos campos da comunicação social e do jornalismo, perderemos de vista as possibilidades que ora temos de 
reconfigurar os olhares em relação a estes campos.

Em uma perspectiva mais ampla, queremos ressaltar que a narrativa, como espaço que a priori explicita a problemática da enunciação, só muito recentemente tem sido considerada objeto de estudos no campo do jornalismo. A especificidade do campo dos media, para Adriano Rodrigues. reside no fato de que a discursividade, a narratividade e a tecnologia sejam elementos nodais na sua própria constituiçãoº . E no aspecto que aqui abordamos, um dos vértices desse triângulo - o da narratividade - parece ter sofrido uma relativa negligência, ou pelo menos ter sido preterido em relação aos outros dois.

No contexto atual, as narrativas têm um papel relevante, primeiro porque nelas são tecidos os saberes acerca do mundo. depois porque. a partir delas, outros saberes são construídos. Em outras palavras, se há alguma mediação possível, pelo menos em se tratando do campo dos media, ela acontece na e através da narrativa. Para Adriano Rodrigues, os meios. que ele chama de "máquinas narrativas":

Asseguram (...) ao mesmo tempo a continuidade e a rotura. actualização da Grande Narrativa fundadora e corte numa multiplicidade de pequenas narrativas menores. prolongamentos mediáticos do imaginário ancestral e produção de uma racionalidade quotidiana. de um efeito de realidade. Dupla pertença: ao imaginário ancestral e à quotidianeidade, fonte de uma nova estratégia legitimadora da divisão e da rarefacção do espaço. (1984:63. grifo nosso)

Ou seja, as "pequenas narrativas" - diversas. plurais e inumeráveis. como bem diz Roland Barthes (1971) - tornam-se importantes elementos a serem investigados, porque conferem legitimidade e redividem, socialmente, o espaço no qual elas pertencem; observação relevante que nos faz pensar na importância do campo dos media. Para Appadurai, por exemplo.

o grande discurso acerca da modernização desenvolvimentista (crescimento econômico, alta tecnologia, negócios agrários. educação, militarização) ainda persiste em vários países. No entanto, é frequentemente pontuado. questionado e redefinido por micronarrativas de filmes. televisão. música e outras formas de expressão que permitem que a modernidade seja reescrita (...). (1996:10)

O trabalho de Appadurai é particularmente relevante no contexto da nossa reflexão porque, na perspectiva das migrações e da inscrição do meio eletrônico na sociedade, o autor reavalia o papel da imaginação na 
reconfiguração do espaço social. No mundo pós-eletrônico, segundo esse autor, devido ao próprio avanço tecnológico, ocorre uma mudança sistemática e significativa no que diz respeito à imaginação porque ela rompe o espaço da arte, do mito e do ritual para tornar-se parte do "trabalho mental cotidiano" de pessoas comuns em muitas sociedades (1996:5). O que para a nossa reflexão revela-se como significativo é o fato de que todo o trabalho de imaginação, pensado por Appadurai como fundamentalmente social, deriva das narrativas mediáticas. O próprio autor entende que "a mídia eletrônica marca e reconstitui um campo muito mais amplo, no qual os meios impressos e outras formas orais, visuais ou auditivas de mediação continuam a ser importantes" (1996:3).

Sob essa ótica, vemos a narrativa como uma forma de representação coletiva, como um elemento que cria e recria sociabilidades, como práticas comunic tivas sociais que definitivamente contribuem, na sociedade mediatizada, para o alargamento dos horizontes de experiência. E nesse aspecto, é fundamental que as pesquisas no campo do jornalismo estejam também atentas às formas de narrar o mundo. Não exclusivamente ao conteúdo das mensagens que se passa, mas, principalmente, às dimensões éticas e estéticas que, da perspectiva das mediações reposicionam os campos e os atores sociais, oferecendo a eles possibilidades de existência.

Em suas reflexões sobre o narrador na obra de Nikolai Leskov, ${ }^{3}$ Walter Benjamin diz da arte de narrar como atividade em vias de extinção. O dilema que $o$ autor parece viver nos anos 40, de algum modo, ilumina a problemática vivida na contemporaneidade. Se o ato de narrar, de acordo com as constatações de Benjamin, perde sua vitalidade no momento de exacerbação de uma prática cotidiana burocratizante e limitadora (processo advindo de um projeto que visa a modernizar o homem e o mundo), no atual momento, é o ato exacerbado de um narrar burocratizado, em meio à proliferação de narrativas, que impõe a reflexão sobre si próprio. Do ponto de vista teórico e prático, o jornalismo traz pressupostos que o torna um campo muitas vezes restrito a produções pouco atentas às práticas cotidianas e culturais da contemporaneidade. $\mathrm{E}$ assim, o ato de narrar, quando burocratizado pelas fundamentações epistemológicas do discurso jornalístico, torna-se limitado e limitador.

Assim, nesse ensaio, a partir da reflexão que propomos, queremos sugerir que a narrativa, em seu caráter dinâmico e social, possa se fazer presente nas análises e nas reflexões sobre a sociedade que constrói (e se reconstrói com) os meios de comunicação. Nesse sentido, as narrativas, porque cumprem a função de tecer a existência entre os meios e a sociedade, são elementos essenciais. E sob essa perspectiva, parece-nos fundamental ressaltar que a problemática da enunciação, tanto no campo da comunicação social como no caso específico do jornalismo, é uma questão central, aspecto sobre o qual nos debruçaremos mais detidamente. 
O olhar que Benjamin lança ao narrador de uma "verdadeira narrativa" em comparação ao narrador do mündo moderno pode ser bastante esclarecedor para se compreender e até encontrar outras possíveis reflexões e práticas para o narrador-jornalista do mundo contemporâneo. Do ponto de vista epistemológico, o conhecimento que se tem produzido acerca do jornalismo enquadra suas narrativas em um lugar tão formatado que se torna larefa difícil estendê-las a procedimentos dialógicos e polifônicos. Trata-se de narativas, en princípio autoritárias, exatamente porque propõem o apagamento daquele que fala. O jornalista, diante de pressupostos conceituais que formatam o seu textoa necessária busca da verdade, valor encravado na pressuposta imparcialidade de quem relata o fato - se esvai do narrado e raramente se apresenta enquanto autor. Não há, na perspectiva da narrativa jornalística tradicional. alguém que conta a história. Desse modo, à luz das reflexões de Benjamin. esperamos que seja possivel refletir sobre a problemática da enunciação, questão que, no nosso entender, tem limitado a práxis jornalística a una ordem de caráter condutista.

Para Walter Benjamin, a faculdade de intercambiar experiências tornase cada vez mais precária. E, sob essa ótica, a arte de contar histórias encontra o primeiro indício de sua morte no surgimento do romance. no início do período moderno. De acordo com Benjamin, o romance "nem procede da tradição oral nem a alimenta" (1985:201), o que o torna distante daquilo que o autor compreende como narrativa: conceito que não se apreende ipsis literis do texto de Benjamin, mas que se deduz a partir das condições por ele impostas ao narrador de uma "verdadeira narrativa". Tais condiçōes estão sempre relacionadas à experiência de quem narra, de modo que não há narrativa, pelo menos é o que se pressupõe através das reflexões de Benjamin. sem que o narrador possa cumprir uma de suas funções fundamentais: dar conselhos. Essa tarefa, que dá à narrativa sua dimensão utilitária, é cada vez menos provável, se se considerar, como diz Benjamin, que "as experiências estão deixando de ser comunicáveis" (1985:200).

No entanto, para que seja possível redimensionar a problemática levantada por Benjamin, há que se compreender o ato de narrar não como o que provém tão-somente da oralidade: ele é, por excelência. fruto da necessidade que o homem tem de contar e recontar. de um para outro. as histórias que permeiam sua vida. E esse contar pode nascer, hoje principalmente, nos vários lugares em que a vida acontece. Mais ainda, o ato de narrar deriva da premência de se estabelecerem modos de compreensão e entendimento do mundo em que se vive. Para Norval Baitello Júnior.

Narrativizar significou e significa para o homem atribuir nexos e sentidos, transformando os fatos captados por sua percepção em símbolos mais ou menos complexos, vale dizer, em encadeamentos, correntes, associações de alguns ou de muitos elos sígnicos. (1999:37) 
Além disso, em um segundo momento, há que se admitir o ato de "experienciar" o mundo com outros contornos, distintos daqueles com os quais traabalhava Benjamin. A experiência, na sociedade pós-industrial, ganha outras conotações. Ela tanto deixa de dérivar puramente de um tempo estritamente ligado ao real, como também passa a ser, de modo muito mais märcante que em outras épocas, causa/efeito de um significativo processo de midiatização das narrativas. Tais fatores permitem ao narrador, assim como à narrrativa, ocupar um outro lugar, em outras condições e, até mesmo, com outras funções.

\section{O romance e seu princípio: o reconhecimento do problema}

A problemática da narrativa trazida por Benjamin importa a esta reflexão, particularmente, por nela ser possível encontrar indícios da questão do atrofiamento que apontamos na compreensão e na produção da narrativa jornalística. Seu texto, por cuidar particularmente da perspectiva da narração, ajuda a marcar e redimensionar os lugares e os papéis do narrador, fornecendo pistas para que se compreendam os obstáculos que atravessam o processo de construção das narrativas. Se a "verdadeira" nárrativa de que fala Benjamin apresenta-se intrinsecamente ligada à tradição oral, há que se entender a relação desta com o romance propriamente dito. Segundo o autor, o romance

90 é o indício de uma morte que se anuncia, é a conformação do narrador à condição de quem não mais conta a partir da experiência, sua e/ou a dos outros. Com o romance, morre a narrativa porque perdè-se a troca que antes se dava pela via do relato interpessoal. E, nesse sentido, se se trabalha com as características do narrador no momento em que surge o romance, Benjamin tem razão.

Por exemplo, Pamela, ${ }^{4}$ de Samuel Richardson, considerado um dos exemplos precursores do romance moderno (WATT, 1990), em meados do século XVIII, rompe com uma certa tradição no ato de narrar. Nele, as perrsonagens são nomeadas ${ }^{5}$ e há uma preocupação com a questão temporal - trata-se de um romance epistolar e as cartas eram escritas diariamente. São estas observações importantes para que se possa contertulalizar o surgimento do que se entende como romance, mas são a presença e o papel do narrador em Pamela que poderão melhor esclarecer as reflexões de Benjamin.

À luz da teoria literária, entendè-sè como se apresentam, nas narrativas, os sujeitos do enunciado e o da enunciação. Para Schüler, o narrador é parte do universo imaginário do autör, o que impede que ambos sejam vistos como uma única peessoa. "O narrador (sujeito do enunciado) não pode ser o mesmo que o autor (sujeito da enunciação)" (1989:28). O enunciado, as frases que constituem a história, é o fato narrado (fazendo referência a um universo 
mais familiar para o campo da comunicação), e a enunciação é o ato de narrar. processo no qual se tece a história.

Em Pamela, notam-se as marcas do narrador - sempre presente em qualquer texto - seja na descrição do cenário. na caracterização das personagens ou até mesmo nos valores morais que são impostos pelo olhar e pelas ações das personagens. Além disso, o que parece mais significativo, há interferências diretas na narrativa de Richardson. Por exemplo: "Neste ponto faz-se necessário que o leitor saiba que os justos julgamentos de Pamela ainda não chegaram ao fim". "Tal interferêncial é usada para explicar o que se passa na história, evidenciando a presença e o papel do narrador.

No entanto, essa mesma interferência, segundo Watt, chama atenção para a presença do autor na narrativa, fazendo com que se confundam os sujeitos do enunciado e o da enunciação. Ao leitor de Pamela. dessa forma. resta sempre a dúvida quanto ao papel de Richardson: será ele quem conta a história? Será o próprio Richardson quem julga o componamento das personagens? Por tratar-se de uma narrativa em primeira pessoa. o que já a torna limitada e unilateral. tal interferência provoca no leitor a confusão entre autor e narrador. Confusão que persiste em outras obras que marcam o início do romance. ${ }^{7}$

Se, em uma perspectiva histórica, entendemos o processo de mudança por que passam o narrador e o autor, a reflexão de Benjamin torna-se mais compreensível. É somente em Pamela, ou melhor, nas primeiras manifestações do romance, que sua análise se legitima: nas primeiras narrativas romanescas. autor e narrador se confundem, dado que faz com que aquelas sejam narrativas autoritárias, responsáveis pela morte anunciada por Benjamin (1985).

\section{No jornalismo: narrativas?}

Ao reclamar de uma certa atrofia que envolve o processo de construção das narrativas, Benjamin detecta o momento crucial em que a experiência da comunicabilidade ganha outras nuances. De algum modo. ele antevê o que esse fato significaria para o exercício da comunicação propriamente dita. Aos seus olhos, existe algo ainda mais ameaçador à narrativa do que o próprio romance; trata-se da informação. Para o autor.

a informação aspira a uma verificação imediata. Antes de mais nada ela precisa ser compreensível "en si e para si". Muitas vezes não é mais exata que os relatos antigos. Porém, enquanto esses relatos recorriam frequientemente ao miraculoso, é indispensável que a informação seja plausivel. Nisso cla é incompatível com o espírito da narrativa. Se a arte da narrativa é hoje rara, a difusão da informação é decisivamente responsável por esse declínio. (1985: 203) 
Um dos aspectos significativos na análise de Benjamin é que para tratar da problemática que envolve a narrativa no momento da constituição do romance, ele faça referências à informação, um dos elementos fundantes do jornalismo. Como confirma Benjamin com relação ao papel do narrador no romance, o jornalismo, principalmente quando se restringe à função básica de informar, pouco contribui para a construção de narrativas, no sentido amplo do termo. Ao contrário, produz relatos atrofiados ou monológicos que, para Cremilda Medina (1996), muitas vezes, se formulam no exercício do jornalismo. E o fato de Benjamin basear-se nas primeiras manifestações do romance e ainda determinar a difusão da informação como dado a contribuir para que se anuncie a morte da narrativa só vem confirmar a hipótese de que essa atrofia detectada nas narrativas jornalísticas tem, em princípio, as mesmas origens de que fala Benjamin.

Nas narrativas jornalísticas, o ato de narrar é uma problemática a ser enfrentada. Nelas, a forma autoritária de narrar as histórias mantém-se, e, de certa forma, com muito mais agravantes por apresentar-se velada. Envolto no real e na verdade como referentes, além de trazer a imparcialidade e a objetividade como operadores, o discurso jornalístico tradicional - aquele que é epistemologicamente reconhecido - dispõe de escassos recursos com os quais narrar os fatos do cotidiano.

Ao se retomar a problemática que envolve os sujeitos constitutivos das narrativas, percebe-se que, no jornalismo, assim como nas primeiras manifestações do romance, o sujeito do enunciado (o narrador), na grande maioria das vezes, confunde-se com o da enunciação (o autor, nesse caso, o jornalista). Primeiramente, e aqui se diz de uma perspectiva epistemológica, porque a enunciação é totalmente subordinada ao enunciado - para o discurso jornalístico, que opera segundo a verdade dos fatos, o que interessa é o fato em si. O como narrar esse fato, a enunciação propriamente dita, resume-se à utilização de uma técnica. $O$ jornalista, a rigor, não escolhe como narrar. A ele são "oferecidos" condicionantes que regulam e delimitam o seu campo de atuação - sejam as técnicas que impõem o uso do lead ou, além de outros determinantes, as questões mais subjetivas que o obrigam a se restringir à "verdade" e aos dados factuais.

Mais ainda, hoje, manuais de redação ditam as regras sobre as quais se deve fundar a narrativa jornalística. E, desse modo, além de legitimar as regras com as quais se deve produzir o efeito de verdade, a existência de tais manuais propicia aos jornalistas uma aparente neutralidade. Assim, o jornalista, restrito às formas/fórmulas que regem o discurso jornalístico, raramente consegue transpor o lugar ocupado pelos primeiros romancistas. Se estes, na história da narrativa romanesca, vêm alterando as formas de narrar e com isso conseguindo ultrapassar barreiras, fazendo-se menos segregados, o mesmo não acontece com o jornalista. ${ }^{8}$ 


\section{O narrador-jornalista: outro modo de desvelar os fatos}

Em matéria publicada na Folha de S.Paulo. no dia 15/04/02. Clóvis Rossi chama atenção para a problemática que é sempre un dos grandes desafios do trabalho jornalístico:

É muito possível que jamais se conheça com perfeição o que aconteceu de fato no campo de refugiados de Jenin. $103 \mathrm{~km}$ ao norte de Jerusalém, exatamente o local em que houve o maior número de vítimas da reocupação por Israel de cidades palestinas.

Essa perspectiva ficou claramente aberta quando uma equipe da agência Reuters conseguiu entrar no campo. no sábado. para chegar à conclusão de que comprovar o que de fato houve é uma tarefa extremamente difícil, se não impossivel."

A questão da verdade. ou melhor. das verdades, tratada no campo do jornalismo como uma problemática filosófica, aflige o profissional que, no ato de enunciar. vê-sc condicionado a encontrar a verdade do fato. Essa é uma problemática que acompanha o exercício jornalístico. desde sua formação - a própria questão dả censura está vinculada à condição de se proferir verdades $-\mathrm{e}$ ass soluções que têm sido encontradas. até agora. passam pelos autoritarismos e/ou pelas técnicas. $O$ impasse. de qualquer modo, é travado: não há uma verdade (para os fílósofos, uma questão de fundo teórico) e ainda assim deve-se buscá-la (para os jornalistas, uma questão de fundo prático).

Encontrar a verdade. de alguma maneira, é um legado deixado ao homem moderno, resquício de uma prática de enunciação divina. Do ponto de vista histórico, se se pensa na modernidade acometida pela morte do Primeiro Locutor ${ }^{10}$. torna-se compreensível a desolaçĩo que sofre o sujeito moderno que se vê fadado a fazer a sua fala, em substituição à fala do Outro." O abandono da idéia de uma enunciação demiúrgica como lugar legítimo da fala impõe interrogantes ao ato de enunciar: primeiro. o significado do ato: em seguida, quem enunciará a partir de então.

Com o advento das sociedades modernas. vê-se a formação de um espaço público cada vez mais marcado por categorizações. A Revolução Industrial é um acontecimento histórico que contribui para a segmentação da sociedade, ressignificando papéis a serem desempenhados. A mudança no tecido social, que ocorre nos períodos seguintes, cria setores considerados ora mais ora menos legítimos. ${ }^{12}$ E. nesses setores, alguns sujeitos fazem-se mais locutores que outros: 
Cresce agora um novo rei: o sujeito individual, senhor inapreensível. Ao homem dá cultura esclarecida se acha transferido o privilégio de ser, ele mesmo, o deus outrora "separado" de sua obra e definido por uma gênese. Sem dúvida, entre os atributos do Deus judeu-cristão, os seus herdeiros burgueses fazem uma triagem: o novo deus escrevè, mas não falä; é autor mas não se palpa nenhum corpo em uma interlocução. (CERTEAU, 2000:251) Esses locutores, que aos poucos seguem ancorando-se em razốes científicas formais e instrumentais, nằo só se tornam "novos reis", mas também fundemse em novos deuses através de quem eles falam. $\mathrm{O}$ anúncio de outras verdades, dessa vez categorizadas em lógicas sociais, econômicas e/ou políticas, é legitimado em suas falas. A busca da verdade, sob essa ótica, dáse por uma razão de sobrevivência: é preciso que alguém a conheça e, conhecendo-a, que conte ao outro. Em outras palaviras, a morte do Primeiro Locutor elimina a fala divina, mas não impede - ao contrário, provoca - a criação de outras divindades e outras práticas enunciativas detentoras de outras verdades. Dessa maneira, resolve-se uma das interrogantes impostas ao ato de enunciar: a problemática do quem deve proferir tal ato.

No encalço dessa questẩo, vinha mais uma - se o que cabe ao homem não é mais tão-somente ouvir o que é dito, mas fazer/provocar o ato de fala, a pergunta é simples: de que lugar deverá esse ato ser provocado? É na desembocadura do moderno que essa questão é suscitada, e é nesse mesmo lugar que todo um processo histórico-cultural se constitui e contribui para que a resposta seja dada. Se rão há um lugar divino, há que haver outros que não só legitimem a fala, mas que também determinem como ela deverá ser feita. Volta-se às variantes estruturais do discurso, o quem e o como são agora problemáticas de uma dimensão ainda maior, a que vișa a dar solução à falta da grande Fala. Nesse aspecto, se o "lugar" literário é privilegiado, já que por princípio seu objeto é a ficção, o lugar próprio da não-verdade, o jornalístico, somado ao histórico, ao jurídico e ao científico de modo geral, legitima-se como um lugar a mais do qual se profere a verdade. Assim, o enunciado perde o lugar como fala divina, mas continua dominante como fala legitimada.

No entanto, a outra interrogante imposta à problemática da enunciação, o significado / o sentido do ato de enunciar, não se resolve. Michel de Certeau identifica no processo de burocratização da eścrita o recalcamento da problemática que circunda o ato de enunciar. Porque nele se inscreve um sistema, um modus operandi dotado de uma fundamentação que lhe é externa, problematizá-lo no que ele traz de sentido torna-se pouco significativo. Mais fácil ceder a questão à literatura (no exercício da prática) e à teoria literária (no que tange à reflexão), que deverão então tratar de desenvôlvê-la e compreendêlả, já que parece ser lá o lugar em quie èla pode se fazer mais complexa. Assim, para Certeau, "a inquietude da enunciação se encontra portanto a priori liquidada, antes de voltar hoje como problema da comunicação". (2000:251) 
Toda a sistematização da escrita que se operacionaliza a partir dessa lógica é. além de tudo, um esforço de obliteração da falta do Locutor Primeiro. No entanto, como todo recalque, o retorno é inevitável. Como exemplos, há os cientistas-deuses que, pela própria inexatidão da física, passam a ser (re)vistos e/ou lidos com outros olhos; há os detentores do saber histórico que, pelas vias de uma história nova, começam a (re)pensar as fontes e o discurso que produzem de modos menos estanques. ${ }^{13}$

Entretanto. no que diz respeito ao jornalístico, a prática de construção de um discurso recalcado tem provocado justificativas (ainda que somente aos "grandes" jornalistas seja permitido fazer). Clóvis Rossi. no dia 04/04/02. antes de dar início à cobertura que faria dos acontecimentos em Jerusalém. anuncia:

Em nome da transparência que a Folha tenta praticar, algumas informações preliminares:

1 - Não sou judeu nem árabe. Logo, ao menos em tese. o sangue não vai enviesar meu trabalho (...)

2 - Não obstante, sou fascinado por esta região do mundo. Sempre que entro em Jerusalém, sinto o peso de 3.000 anos de história e da mística religiosa da única cidade do mundo que abriga locais há séculos reverenciados como sagrados pelas três grandes religiões monoteístas.

3 - o fascínio se estende aos judeus. sei lá por quê. ${ }^{14}$

Rossi, após dizer que Ehud Barak, ex-ministro de Israel, atesta ofim da "superioridade moral" do seu país, estende-se dando informações acerca da belicosidade e da crueldade israelenses, de alguma maneira, desculpando-se pelo enunciado final que seu artigo traz: "Dificil, pois, discordar de Barak". Sua denúncia acerca da impossível imparcialidade reflete, de alguma maneira, a angústia que sofrem os pequenos deuses portadores da verdade factual.

No caso do jornalístico, portanto, o recurso tem sido a autodenúncia de alguns ou a complacência que se espera dos vários, os que não podem justificar-se. Estes portam-se como senhores-sabe-tudo - não necessariamente porque assim se sintam ou porque assim o queiram — mas por terem suas falas legitimadas (diante das perspeciivas históricas que aqui estão sendo traçadas) por estratégias textuais que regem o enunciado que eles construirão. Há. é importante ressaltar, inserções reflexivas e pragmáticas de alguns pensadores que têm feito seus trabalhos convergirem no confionto com a problemática, propondo pensar novos possíveis lugares para ? jornalismo. ${ }^{15}$ Entretanto. o papel mitificado do jornalista ainda insiste em se 
fazer presente, o que deixa o campo em relativo atraso, quando comparado ao científico e ao histórico.

Vale ressaltar, as narrativas atrofiadas, em seu processo de construção e constituição, são coniventes e ao mesmo tempo alimentam a prática demiúrgica, pelo simples fato de sustentarem a (e de se sustentarem na) ilusão do encontro com a verdade. É o mesmo Rossi, que, já em São Paulo, de volta do trabalho em Jerusalém, reflete sobre sua angústia, agora de modo a revelar a frustrante "missão" de quem sai em busca da verdade:

Nunca, em quase 40 anos de profissão, voltei de uma missạo cọ̣ um travo tão amargo de frustração como no caso da cobertura do conflito israelo-palestino. Um travo amargo que tem nome e sobrenome: campo de refugiados de Jenin, no qual houve um massacre segundo os palestinos, e apenas um combate feroz, de acordo com Israel. ${ }^{16}$ (Grifo do autor)

Essa é a fala de um jornalișta que, naa sua "árdụa misșão" - porque impossível - de desvendar e narrar as verdades do fato, perde o sentido do olhar e pensa poder narrar uma história tão-somente porque vê. Ele próprio se denuncia na sua ilusão: "A frustração no caso de Jenin se dá porque as versões de um lado e de outro são absolutamente incompatíveis, e não havia ụm só jornalista presente na hora dos fatos para ter a sua própria versão."17

É importante sublinhar o que Rossi não demonstra ter percebido; as versões, na grande maioria das vezes, são incompatíveis e, mais angustiante ainda, o simples fato de estar presente para ver não faria a versạ̃o de quem viu mais compatível que as outras. É demasiạo frustrante, não hạ dúvida, contar sem narrar, principalmente porque as condições epistemológịcas impostas ạo jornalista são reducionistas em relação ạo ato de enunciar. O máximo que se consegue, nesses casos, é mostrar aquilo que se viu e/ou ouviu. Volta a problemática da enunciação, ela não se resolve na voz dos pequenos deuses.

No entanto, é nas narrativas do mesmo Rossi, na cobertura do mesmo acontecimento, que encontramos algumas tentativas de resposta às questões que ele próprio levanta. Encontramos um outro texto e, portanto, chegamos ao fato de outra maneira, quando o autor permite diluir sua fala na de um outro, no caso um narrador, agindo de modo distinto do que fazia o romance em seus primórdios e do que faz o jornalismo cujas narrativas se constituem a partir de técnicas e conceitos que pressupõem sua forma:

Uma cabeça ensangüentada e um rosto que parecia ter perdido a pele, ressaltando apenas os dentes, permaneceu estendido na calçada em frente à padaria da rua Jaffa, a loja mais próxima do ponto de ônibus em que foi praticado $o$ atentado de ontem. 
Só às 17 h45 ( 11 h45 em Brasília), o corpo foi removido, no saco de plástico negro com o número 10 pregado. Foi apenas uma das cenas de horror vistas e vividas ontem nessa rua tão central e tão característica de Jerusalém. ${ }^{18}$

O narrador - sim, porque aqui se sente a presença de um outro que vê - conta os detalhes da cena, do fato jornalístico. Ele é contundente e faz enxergar o que se passa. Não há qualquer preocupação com a questão da objetividade, por exemplo, e, no entanto, difícil pensar em cena mais objetivamente descrita. Escapamos nós mesmos da visão do jornalista, olhamos o fato e, com aquele que narra a história. nos tornamos parte dele. Além disso, a narrativa se estende e o olhar do narrador faz ver e sentir que a verdade, de fato, está na contradição das versões. Após contar e fornecer os dados factuais/fatais (portanto, objetivos e subjetivos) do acontecimento. ele traz à tona tanto o olhar dos israelenses como o dos palestinos; o narrador (que, vale dizer, não é o jornalista se fingindo de narrador) termina sua sondagem:

E um homem de roupa toda preta, kipá idem, gritava junto à cerca que isolava o local do crime: 'Eles nos matam. nós os matamos'. Em seis palavras, uma descrição crua do que está ocorrendo em Israel e nos territórios palestinos."19

Na perspectiva do texto, a frustração de Rossi se faz menos justificável. No conjunto das notícias que ele publicou acerca dessa guerra, várias são as que viabilizam o olhar de um narrador que marca o texto. deixando transparecer a contradição das versões, sem obrigatoriamente ter de apresentar uma terceira. O seu próprio texto nega a sua premissa: narrar as verdades dos fatos independe de encontrar uma verdade. É preciso sublinhar. não é questão. nesse caso, procurar saber se o jornalista (real) foi acometido pelo acontecimento e por isso produziu um texto demasiadamente emotivo e/ou imparcial. Tal atitude ainda é de quem procura desvendar o fato verdadeiro. A intenção aqui, antes que seja conceituar e qualificar o texto, é deixar vir à tona, através dele, o exercício de uma tessitura mais complexa que a imposta aos jornalistas deificados. No caso específico dessa matéria sobre um dos vários atentados que têm acontecido em Jerusalém - portanto um fato cotidiano local - saltam aos olhos as considerações de Silviano Santiago acerca da postura e do papel do narrador pós-moderno que. de acordo com esse autor, é o narrador-jornalista:

São essas as posturas fundamentais do homem contemporâneo. ainda e sempre mero espectador ou de ações vividas ou de ações 
ensaiadas e representadas. Pelo olhar, o homem atual e narrador oscilam entre o prazer e a crítica, guardando sempre a postura de quem, mesmo tendo se subtraído à ação, pensa e sente, emociona-se com o que nele resta de corpo e/ou cabeça. (1989:51)

Em um texto habitado pelo narrador-jornalista, o seu criador é liberado da obrigação de revelar qualquer verdade que seja; é o narrador quem observa e conta a história, subtraindo-se da ação narrada (pressuposto máximo da narrativa jornalística), sem ter de enfrentar a empiria implícita ao mundo real. Ele é uma estratégia textual, e é no texto que ele se revela. O jornalista (autorempírico), que precisa de habilidade para saber criá-lo, faz dele o seu olhar, naturalmente, mas não se faz nele. Relembre-se Watt (1990), não há que se confundir o sujeito da enunciação com o sujeito do enunciado. A segunda instância corresponde à do narrador-jornalista, e é através do olhar dele, como é o caso dos romances que hoje se fazem mais próximos à língua dos homens, que o fato se processa.

É esta uma tentativa de rearticular modos de conceber e compreender a narrativa jornalística. De modo a emoldurar-se em uma epistemologia de caráter condutista, o discurso jornalístico e aquele que sobre ele se tece refletem a ordem dominante: há um sujeito da fala, conhecedor, que se dirige a um outro, o seu objeto de escuta. Problematizar o caráter demiúrgico que tem sustentado esta prática implica um longo e delicado percurso, o que demanda $o$ (re)conhecimento de algumas das questões que precedem e ao

98 mesmo tempo constituem as condições epistemológicas que (de)limitam o campo de reflexão e as práticas jornalísticas.

\section{Referências bibliográficas}

APPADURAI, Arjun. Modernity at large - cultural dimensions of globalization. Minneapolis: University of Minnesota Press, 1996.

BAITELLO JÚNIOR, Norval. O animal que parou os relógios: ensaios sobre comunicação, cultura e mídia. São Paulo: Annablume, 1999.

BAKHTIN, Mikhail. Questões de literatura e estética: a teoria do romance. São Paulo: Unesp, 1998.

BARTHES, Roland. Análise estrutural da narrativa. Petrópolis: Vozes, 1971.

BENJAMIN, Walter. O narrador - considerações sobre a obra de Nicolai

Leskov. In: . Magia e técnica, arte e política. São Paulo:

Brasiliense, 1985. p. 197-221.

CERTEAU, Michel de. A invenção do cotidiano. Petrópolis: Vozes, 2000.

HABERMAS, Jürgen. Mudança estrutural da esfera pública. Rio de

Janeiro: Biblioteca Tempo Universitário, 1986. 
MEDINA, Cremilda. Povo e personagem. Canoas: Uibra. 1996.

MIĖGE, Bernard. El espacio público visitado de nuevo (I) e (II). In.

La sociedad conquistada por la comanicación. Barcelona:

ESRP/PPU, 1992.

RESENDE, Fernando. "O olhar às avessas - a lógica do texto

jornalistico”. São Paulo: ECA/USP, 2002. (tese de doutoramento)

The story-teller: an analysis of the narrator in five different

narratives - from Richardson to Barth. Belo Horizonte: Faculdade de

Letras da UFMG 1993. (Mimeo).

RICHARDSON. Samuel. Pamela. Dutton: Everyman`s Library. 1962. 2 v.

RODRIGUES, Adriano Duarte. Estratégias da comunicação. Lisboa:

Presença, 1990.

O campo dos media - discursividade, narratividade,

máquinas. Lisboa: A regra do jogo, 1984.

SANTIAGO, Silviano. O narrador pós-moderno. In: . Nats

malhas da letra. São Paulo: Cia. das Letras, 1989. p. 38-52.

SCHÜLER, Donaldo. Teoria do ronance. São Paulo: Ática, 1989.

WATT, Ian. A ascensão do romance. São Paulo: Cia. das Letras. 1990.

WILLIAMS, Raymond. Culura e sociedade. São Paulo: C.E.N. 1969.

\section{Notas}

'Cf. MIËGE, Bernard.

El espacio público visitado de nuevo (I) e (II). In: MIĖGE.

La sociedad conquistada por la comunicación

Barcelona: ESRP/PPU, 1992.

O autor trabalha com a noção de conflito entre os diversos atores e campos sociais, como a nova ordem que rege o espaço público contemporâneo. Para a discussão acerca dos media e do espaço público. o trabalho de HABERMAS , Jürgen. Mudança estrutural da esfera pública. Rio de Janeiro: Biblioteca Tempo Universitário, 1986, é de fundamental importância.

2 Ver, nesse sentido, um importante trabalho de RODRIGUES. Adriano. D.

O campo dos media - discursividade. narratividade, máquinas. Lisboa: A regra do jogo, 1984. O autor discute a "tríplice componente" que delimita o campo dos media como instituição social. Outros trabalhos posteriores têmo mérito de discutir as particularidades a que estas especificidades estão sujeitas. mas o trabalho citado traz a discussão mais geral acerca do assunto.

${ }^{3}$ Cf. BENJAMIN, 1985. p. 197-221.

${ }^{4}$ RICHARDSON, $1962.2 \mathrm{v}$.

5 Não que antes elas não o fossem. mas os primeiros romancistas se interessavam por "mostrar que a personagem deve ser vista como uma pessoa particular, e não como um tipo". 
WATT, 1990. p.21.

${ }^{6}$ RICHARDSON, 1962. v.1, p.76. (Tradução livre do original: "Here it is necessary the reader should know that the fair Pamela

's trials were not yet over...")

${ }^{7}$ É preciso ressaltar, entretanto, que esse tipo de narrativa não se limitou às suas primeiras formas. Um breve histórico revela que o narrador, à medida que a narrativa romanesca sofre alterações, cumpre diferentes papéis, abrindo perspectivas para que se rompa com a mitificação da figura do autor. $\mathrm{Na}$ verdade, o que ocorre é que o narrador parece tornar-se, mais veementemente, um recurso da ficção, deixando o autor restrito ao campo do rèal. Em RESENDE, 1993, procuro esboçar um quadro histórico que visa compreender a presença e o papel do narrador no romance, desde suas primeiras manifestações até o romance dito pós-moderno.

${ }^{8}$ Uma interessante observação de Bakhtin (1998), diz que o romance, na medida em que evolui e distingue as figuras do autor e do narrador, passa a falar a língua dos homens.

${ }^{9}$ ROSSI. História verdadeira pode estar sepultada para sempre. Folha de S.Paul, 15 abr. 2002. Caderno Mundo, p.A12.

${ }^{10}$ Para Michel de Cearteau, "A virada da modernidade se caracteriza em primeiro lugar, no século XVII, pela desvalorização do enunciado e pela concentração sobre $o$ ato de enunciar, a enunciação. Quando se tinha certeza quanto ao locutor ('Deus fala no mundo'), a atenção se voltava para o ato de decodificar os Seus enunciados, os 'mistérios' do mundo. Mas quando essa certeza fica perturbada com as instituições políticas e religiosas que lhe davam garantia, pergunta-se pela possibilidade de achar substitutos para o único locutor: Quem falará? E a quem? Com o desaparecimento do Primeiro Locutor surge o problema da comunicação, ou seja, de uma linguagem que se deve fazer e não mais somente ouvir"(2000:229)

${ }^{11}$ Não cabe aqui uma alusão direta a Lacan, o outro em maiúsculo refere-se ao Deus morto. Todavia, é instigante pensar na hipótese de relacionar essa perda com outra ferida aberta na comunicação: a questão da alteridade.

12 Adriano Duarte Rodrigues, em "A constituição do espaço público moderno", cita o exemplo do barão de Haussmann que no século XIX propõe, do ponto de vista do traçado urbano, romper "com a polifuncionalidade que impedia a especialização racional dos espaços, o que viria a dar lugar aos projectos de desconcentração e segmentação do tecido social". RODRIGUES, 1990. p.34.

${ }^{13}$ Como autores que vêm contestar a posição dos "novos reis" é fundamental citar PRIGOGINE, com O fim das certezas, para o caso do discurso da ciência. Para o discurso histórico, é importante, além de outros autores, WHITE, com Trópicos do discurso.

${ }^{14}$ ROSSI. Belicosidade macabra. 
Folha de S.Paulo, 04 abr. 2002. Caderno Opinião, p.A2.

${ }^{15}$ É vertiginoso, na atualidade, o aumento no número de pesquisas que propõem refletir sobre as dissonâncias entre uma prática jornalística autoritária e uma dimensão teórica mais complexa. Nesse aspecto particular, é fundamental fazer referência ao percurso de Cremilda Medina. Tanto através de suas obras, as já citadas e outras (por exemplo, Entrevista: o diálogo possivel, Profissão jornalista: responsabilidade social), como por via das práticas que a autora tem provocado (o Projeto Plural desenvolvido na ECA/USP, desde 1990), é exemplar), suas intervenções são contundentes no que diz respeito a uma proposta de renovação do olhar sobre os exercícios de pensar e fazer jornalismo.

16 ROSSI. A pergunta que não cala. Folha de S.Paulo, 21 abr. 2002. Caderno Opinião, p.A2.

${ }^{17}$ ROSSI. A pergunta que não cala. Folha de S.Paulo, 21 abr. 2002. Caderno Opinião, p.A2.

${ }^{18}$ ROSSI. Um corpo na calçada, uma cena de horror. Follha de S. Paulo, 13 abr. 2002. Caderno Mundo, p.A20.

${ }^{19}$ ROSSI. Um corpo na calçada, uma cena de horror. Folha de S. Puulo , 13 abr. 2002. Caderno Mundo, p.A20. 
102

CONTRACAMPO 12 